it in such a way as to carry out the objects of the gift. It will require enclosure, supervision, proper maintenance of drains and the continuance of traditional agricultural usage by annual mowing, and closure to grazing of at least certain parts.

\section{Scientific and Industrial Research in India}

IN its report which appeared during the War of 1914-18, the Indian Industrial Commission, over which Sir Thomas Holland presided, directed attention to the necessity of establishing a system of organized research if Indian industries were to be adequately developed. Unfortunately, in the postwar period little attention was paid to these recommendations, although in 1937 the late Lord Rutherford in the presidential address which he had prepared for the twenty-fifth meeting of the Indian Science Congress Association once more emphasized how greatly India would benefit by the formation of an organization similar to the Department of Industrial and Scientific Research. The present War, combined with the energy and foresight of the Hon. Dewan Bahadur Sir A. Ramaswamy Mudaliar, now a member of the War Cabinet, provided the necessary stimulus, and on April 1, 1940, the Board and Council of Scientific and Industrial Research was formed by the Government of India. Dr. (now Sir) Shanti Bhatnagar was appointed as the first director. The manifold activities and the great achievements of this research organization, due largely to the energy of its director, are little known in Great Britain, and we welcome, therefore, the new publication, Journal of Scientific and Industrial Research, issued by the Council, the first number of which has just been received.

The Board functions largely through a series of committees, some nineteen in number, which range from a Vegetable Oil Committee to one of Radio Research. At the present time, the research work of these various committees is carried out, under the general control of the director, in various university laboratories and at the Indian Institute of Science, Bangalore, but a National Chemical Laboratory is to be opened at Poona. This has been made possible by a munificent gift of 8 lakhs of rupees from Messrs. Tata Sons and 1 lakh of rupees from Messrs. Indian Wire and Steel Products Limited. Articles in the Journal discuss the possibilities of the manufacture in India of calcium carbide and thermionic valves and also the utilization of Bhilawan resin as a base for plastics. Interesting articles deal also with established Indian industries such as the Tata Oil Mills and the Juggilal Kamlapat group of mills. While agriculture must always play a predominant part in Indian economy, with her many resources, she can support also great industries. Doubtless future issues of this journal will furnish us with an account of some of these developed by the new research organization.

\section{Industrial Health Advisory Committee}

THE appointment by the Minister of Labour of an Industrial Health Advisory Committee, and the announcement by him of a three-day conference (in April) on industrial health, to which representatives of the Dominions will be invited, as well as representatives of organizations in Great Britain interested in the physical well-being of the working population, indicate a move in the direction of reform long overdue. The rapid mechanization of war, with its consequent emphasis on aceurate large-scale factory work, has directed attention to the time lost in factories through petty illnesses and industrial hazards, mostly preventable. Most, if not all, of these hindrances to production existed in peace-time, but only a life-and-death war, with its vast increase in the factory population, has made it obvious that the standard of health of the factory worker is everybody's business - it is, in fact, a political question. True there are Factory Acts, providing a minimum standard of conditions in factories and protection against many industrial hazards, but their enforcement is entrusted to factory inspectors whose numbers-their zeal has never been in questionare wholly inadequate for the work they have to do. Nor is there much provision for research in industrial health, or much apparatus for the implementation of its findings. One of the duties of this new Committee will be to codify knowledge and help to bring it into use.

A comparatively modern development is the realization of the fact that the health of the worker is not merely the province of medical men and factory inspectors, but also of the worker himself. This is reflected in Mr. Bévin's suggestion that trade unions should take an interest in the preservation of health, and in those from other quarters that workers should help in the defence against industrial hazards and the teaching of industrial hygiene. Mr. Bevin hopes that Government, employers, managers and workpeople will co-operate to the full in providing factory conditions that will make work healthier; safer and more pleasant. 'The Committee will advise him how the Government can do its part. This valuable cooperation, for these honourable ends, must be continued after the end of the War, through the difficult times of transition and on into the era of peace.

\section{British Council: New Institutes in West Africa}

Prof. W. M. Macmillan, who has been working for the past two years in the Empire Intelligence Section of the British Broadcasting Corporation, has been selected by the British Council to act as its representative in West Africa. He will leave for the West Coast as soon as possible. His appointment follows a survey recently made by $\mathrm{Mr}$. C. A. F. Dundas, the British Council's representative in the Middle East. It is hoped to establish institutes in the four West African Colonies, to serve as intellectual and cultural centres and to demonstrate the progress made in Britain in the fields of science, pure and applied, literature, art, music and drama. The necessary executive staff is now being assembled. Prof. Macmillan, lately professor of history and research fellow at the University of the Witwatersrand, Johannesburg, is a member of the Colonial Oifice Advisory Committee on Education in the Colonies. He has spent many years in Africa and several of his books are widely known; they include "Warning from the West Indies" (1936), and "Africa Emergent" (1938).

\section{Mortality and Life Assurance Statistics}

Sir William P. Elderton and Mr. M. E. Ogborn read a paper before the Royal Statistical Society on March 16 on "The Mortality of Adult Males since the Middle of the Eighteenth Century as shown by the Experience of Life Assurance Companies". Life assurance as we know it began in 1762, when the Society for Equitable Assurances on Lives 